\title{
Wealth, poverty and mutual care: Towards a reconstructive reading of the book of Job
}

\begin{tabular}{|c|c|}
\hline \multicolumn{2}{|c|}{$\begin{array}{l}\text { Author: } \\
\text { Philip P. Venter }{ }^{1}\end{array}$} \\
\hline \multicolumn{2}{|c|}{$\begin{array}{l}\text { Affiliation: } \\
{ }^{1} \text { Department of Old } \\
\text { Testament Studies, University } \\
\text { of Pretoria, South Africa }\end{array}$} \\
\hline \multicolumn{2}{|c|}{$\begin{array}{l}\text { Correspondence to: } \\
\text { Philip Venter }\end{array}$} \\
\hline \multicolumn{2}{|c|}{$\begin{array}{l}\text { Email: } \\
\text { venterp@iafrica.com }\end{array}$} \\
\hline \multicolumn{2}{|c|}{$\begin{array}{l}\text { Postal address: } \\
\text { PO Box } 73095 \text {, Fairland 2030, } \\
\text { South Africa }\end{array}$} \\
\hline \multicolumn{2}{|c|}{$\begin{array}{l}\text { Dates: } \\
\text { Received: } 12 \text { May } 2015 \\
\text { Accepted: } 13 \text { Aug. } 2015 \\
\text { Published: } 29 \text { Sept. } 2015\end{array}$} \\
\hline \multicolumn{2}{|c|}{$\begin{array}{l}\text { How to cite this article: } \\
\text { Venter, P.P., 2015, 'Wealth, } \\
\text { poverty and mutual care: } \\
\text { Towards a reconstructive } \\
\text { reading of the book of Job', } \\
\text { Verbum et Ecclesia } 36(3) \text {, Art. } \\
\# 1473,7 \text { pages. http://dx.doi. } \\
\text { org/10.4102/ve.v36i3.1473 }\end{array}$} \\
\hline \multicolumn{2}{|c|}{$\begin{array}{l}\text { Note: } \\
\text { This article represents } \\
\text { a theological reflection } \\
\text { on the Faculty Research } \\
\text { Theme (FRT) of the Faculty } \\
\text { of Theology, University of } \\
\text { Pretoria, entitled Ecodomy- } \\
\text { Life in its fullness. The } \\
\text { theme is portrayed from } \\
\text { the perspective of various } \\
\text { theological disciplines. A } \\
\text { conference on this theme } \\
\text { was held on 27-28 October } \\
2014 \text {. }\end{array}$} \\
\hline \multicolumn{2}{|c|}{$\begin{array}{l}\text { Copyright: } \\
\text { (C) 2015. The Authors. } \\
\text { Licensee: AOSIS } \\
\text { OpenJournals. This wor } \\
\text { licensed under the Crea } \\
\text { Commons Attribution } \\
\text { License. }\end{array}$} \\
\hline \multicolumn{2}{|l|}{ Read online: } \\
\hline 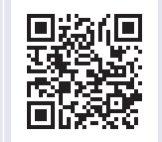 & $\begin{array}{l}\text { Scan this QR } \\
\text { code with your } \\
\text { smart phone or } \\
\text { mobile device } \\
\text { to read online. }\end{array}$ \\
\hline
\end{tabular}

Perceived disruptions between the poetic and prose genres in the book of Job often lead to deconstruction or deconstructive readings of the text. In this article the broad outlines of a possible reconstructive reading are sketched. This revolves around research results regarding the principles inherent to God's address to Job in chapters 38-41. The transformation of Job is shown by comparing his earlier prosperity in the prologue, which he lost, and the description of his newly found prosperity in the epilogue. It will be argued that the epilogue is an essential part of the whole book, and serves to illustrate that Job was indeed transformed by the principles unveiled by the Voice from within the storm. This transformation led to a life which is characterised by its fullness and satisfactory conclusion.

\section{Introduction}

The book of Job concludes with the statement that Job died 'full of days', literally 'satiated with days' (Clines 2011:1241). This statement compounds the issue raised by the epilogue: how is it that a very rich man, who lost everything and became poor, had violent arguments with his friends, and who accused God of being unjust, was simply restored as a rich man with double his previous wealth, and lived a full life? Brenner (1997:298) describes the restoration of Job's wealth and old age as 'belonging to the exaggerated realm of the absurd'. According to Brueggemann (2003:301-302), the book of Job is not about life in its fullness, but rather a book that demonstrates in a dramatic way that the savage reality of loss eventually spares nobody. He argues that the last state of restoration is marked by durable loss because Job received new children, but never again received what he had lost (Brueggemann 2003). In his extensive dissertation, Ngwa (2005) asks the question:

Critical analysis of the Epilogue indicates that there are substantive dissonances between the Epilogue and the preceding poetic section. Given the credibility of these arguments ${ }^{1}$ one wonders whether the final editor placed the Epilogue where it is for nothing. If the character of Job in the Dialogues has progressively and successfully dismantled the theological rationale associated with the nature of retribution in the Prologue, what does the Epilogue again serve by seeming to return to this naive state of awards for the righteous and (threat of) punishment for the wicked? (p. 81)

Yet the author carefully and circumspectly describes in the epilogue not only the restoration of previous wealth, but the doubling of it (as will be expounded below), concluding with a statement that leaves no doubt about satisfaction and fullness as the characteristics of the life of Job. Even Job's lifespan is double the perceived Old Testament expectation, according to Psalm 90:10. Perhaps a reading of the book, including the epilogue, should seriously consider the generic character of the various elements included in it (Newsom 2003:41-47). The prose tale fits neatly into the category of a subversive didactic narrative which opens the door for more nuanced readings of the different characters (Newsom 1996:361), including this 'new', old and rich Job. To disregard the importance of Job's fullness of days, or satiated life, or to regard it as simply God's way of making up for what Job had gone through previously, is to wrongly judge the last scene of the book. The book of Job is not about justifying the actions of God; it is about Job's transformation (Davis 2001:142). This establishes the epilogue as a crucial part of the book as we have it, which must be brought into any assessment of the meaning of the book as a whole.

In the epilogue the transformation of the man Job is illustrated dramatically. Job 42:1-6 portrays the reversal that takes place inside Job. Through the speech of YHWH and the mode of question and answer that is central to it, through the experience that in one speech YHWH keeps reversing the roles between himself and Job, Job can detach himself from his own referential point of view and begin to see through different eyes (Van Wolde 1994:250). In fact, as will be argued below, Job's perspective was already altered by and during YHWH's speeches from inside the storm. 
As a result Job undergoes two transformations: he discovers that most things are beyond his scope, that he does not have the insight, nor could have, in the master plan of creation, and he briefly recognises YHWH's way of looking. Because Job's view changes, there can also be a reversal in his attitude. This change of attitude is enveloped by and infused with the moral and existential lessons that he learned from YHWH during the magnificent engagement with the earth, the cosmos, and the animals in YHWH's monologue in chapters 38-41.

The transformation of Job is lived out in newly found wealth, both socially and economically. Clines (2011:1237) says: 'If the significance of the doubling of Job's possessions is here rightly understood, it is far more than a wry touch; it is critical for the narrative of the book'. I agree with the statement about the significance of Job's wealth, but not with his deconstructive perception that it happens as God's acknowledgement that Job was unfairly treated or wronged. This way of deconstructing the book of Job disregards the centrality and significance of the YHWH speeches from the whirlwind, which, as I will argue, contains the most profound existential, moral and ecological didactic that transforms not only the character of Job, but also modulates the focus of the book of Job. In this regard I do agree with Clines (2011) when he describes what happens in the epilogue as follows:

The focus for the author of the Book of Job seems to have modulated in this epilogue from such questions as 'What is the meaning of the universe?' and 'Is there justice?' to a new question: 'What is important for an authentic human existence?' How to measure the relative value of a solution to the intellectual puzzle of the universe against the delight of dreaming up beautiful names for beautiful daughters? Where stands a claim for cosmic justice against the demands of sociability and familial harmony? (p. 1241)

In this regard Wolfers (1995) errs when he observes that Job has penetrated the truth about the moral conduct of the world by learning that the quality of an individual's life is unrelated to his moral deserts, and:

that disaster is a random occurrence as likely to befall the righteous as the wicked; that God does reject the innocent and reward the wicked as individuals as often as He does the reverse. (p. 462)

To regard Job's poverty and wealth as wilful rejection or reward by God regardless of Job's morality goes against the grain of the book of Job, which revolves around the revelation of a cosmos typified by characteristics like mutual care, interdependence, differentiated unity, homeostasis, interrelatedness and intrinsic worth in the YHWH speeches to Job. ${ }^{2}$ As Gutiérrez (1987:88) puts it: 'Job did not submit to the theology of temporal retribution, after the dialogues; he found a way from the expounding of the environment around him to participate in grace'. A quibble about suffering or guilt

2.For an extensive exposition of the characteristics found in the speeches of God see Venter (2006:189-246) Vroulikheid by die Skeppergod? ' $n$ Liggaamskritiese
Ontleding van geselekteerde Skeppingstekste in die Ou Testament, PhD thesis, University of Johannesburg, and the article in Venter and Viviers (2008). or innocence is of no significance to the inscrutable mystery of life with God that enwraps the entire human endeavour (Brueggemann 2003:298).

I propose that the narrative of the book of Job implies the perspective of the rich and wealthy, a perspective that was fundamentally and positively altered by YHWH's extended address from within the storm. We will therefore revisit the prologue, the epilogue in Job 42, as well as the most important section, that is, God's address to Job in Job chapters 38-41. In the process we will discover a qualitative alternative vision of poverty and wealth which, if embraced, has the potential to destroy that devastating duality and create a new space for both rich and poor; in fact, an answer to the question: What is important for an authentic human existence? We will look out for signs of this authentic human existence in Job's restored circumstances as described in the epilogue, and investigate the cause or causes thereof. Perhaps a new space is created for the wealthy as well as the poor to exist authentically and meaningfully, and even an answer to the quest for life in its fullness, a life 'satiated of days'.

\section{Job's wealth}

Consider Job's wealth. According to the tale, at the beginning he had seven sons and three daughters, and he owned 7000 sheep, 3000 camels, 500 yoke of oxen and 500 donkeys, and he had a large number of servants. He was the greatest man among all the people of the east. This immense wealth is not regarded as problematic, since no questions are raised about one man having such immense wealth that he can own 'very many' slaves or servants. No questions are asked about the social or economic system that produces a narrative in which humans are listed as the property of a rich man, like, and after, sheep and camels and oxen and she-asses. Job is depicted as blameless and upright.

Yet he loses all of this, as well as his health, and this occasioned the extensive conversations, accusations, disputations, as well as God's overwhelming reply and address to Job, to which we will return later. When the storyteller resumes in Job 42, Job is restored and his wealth doubled. It is meticulously detailed that he now had 14000 sheep, 6000 camels, 1000 yoke of oxen and 1000 donkeys. Job also had three daughters. Some scholars suggest, and I agree with them, that a doubling of sons is indicated by the difference in the expressions utilised in the prologue and the epilogue: , thersus 14 (Dhorme 1967:651; Guillaume 2008:492). Perhaps daughters were not 'an index of wealth and status, hence their number is not doubled' (Clines 2011:1237). I prefer to regard the number three as a round and perfect enough figure so as not to detract from the value attributed to the daughters; or, at least, they were very beautiful.

However, this time round there seems to be a correction in the narrative regarding the above-mentioned social and economic system. No mention is made of any slaves or servants. In a narrative where the narrator is particularly 
meticulous in his calculation of the doubling of Job's possessions, this is notable, ${ }^{3}$ as is the difference in regard to his three daughters; no longer are they part of his property, they are granted an inheritance, which meant that they were treated as co-subjects, as participators in the economic system of the family. The names given to the daughters invoke the senses that were extensively challenged when YHWH showed Job aspects of nature and earth: the sense of hearing in Job 38:7, ' ... while the morning stars sang together and all the angels shouted for joy?'; the sense of smell in Job 39:25, 'He catches the scent of battle from afar ...'; and the sense of sight in Job 40:15, 'Look at the behemoth, which I made along with you and which feeds on grass like an ox'.

Furthermore, while no mention is made in the prologue of the ways in which Job gathered his wealth, leaving us to assume that he simply worked hard and that his wealth reflected the things he held dear, his value system, in the epilogue there are clear indications of interaction with friends and family. A mutuality is depicted in the way Job accepted the offerings of cattle and silver and gold, as if to denote that his newly found wealth was built upon his friendly and cooperative interaction with others. As Brueggemann (1994) describes it:

The way in which Job is given twice as much is important for our theme. To be sure, Yahweh guides the process of rehabilitation. But it is of crucial importance for our argument that the mode of restoration is through visible social channels: 'Then came to him all of his brothers and sisters and all who had known him before, and ate bread with him in the house; and they showed him sympathy and comforted him for all the evil that the Lord had brought upon him; and each of them gave him a piece of money and a ring of gold'. Job is given his reward as a just man through the social process. Indeed this human, communal action is stated as a response to God's evil. God may do evil, but redress is done through social process. To be sure, this human action is matched by and corresponds to divine blessing (v. 12). But the divine blessing cannot substitute for social process. It is the work of the human community that makes Job's experience of God's justice possible. Indeed, one may believe it is freshly functioning social processes that permit this rehabilitation. Such processes do not displace divine justice but are the means through which it is practiced and experienced. The fidelity and generosity of God and the equity of the social system both operate. Indeed they function together. Job's vindication is unmistakably through the social system. Our supernaturalist and existentialist readings of Job have not sufficiently recognised that it is the rehabilitation of the social process that is evidenced along with and as the form of God's equity. Indeed our presuppositions have caused us not even to notice that the rehabilitation happens through Job's fellows. (p. 193)

Adding to the above, something must have happened to Job or in Job which occasioned these new profound relationships.

It all starts with the prayer for his friends in Job 42:9, which is accepted by God. It can be regarded as the first selfless act that Job has performed since his misfortunes overtook

\footnotetext{
3.The Stoa school's influence on Israelite literature and other similar sources might 3.The Stoa school's influence on Israelite literature and other similar sources might,
if investigated, provide the reader with examples of the derestriction of the if investigated, provide the reader with examples of the derestriction of the
phenomenon of slavery and demonstrate that this reading is not an instance of a hermeneutics of anachronism. See Wicke-Reuter (2000).
}

him (Clines 2011:1235). This reflects a renewed orientation to the needs of others, and is a sign that Job has abandoned his inward-looking mourning. Moreover, the Hebrew text says that YHWH restored the fortunes of Job while he was praying for his friends, not, as most versions have it, when he had prayed for his friends. There seem to be a qualitative difference as far as Job's restored wealth is concerned, and a shift in his value system is indicated. The epilogue serves to illustrate the effect that God's address had on Job. Therefore chapters 38-41 should be investigated as to the possible shift in a value system that is thereby promoted.

\section{Authentic human existence in Job 38-41}

The observation made previously about an authentic human existence comes to mind when we realise that in the time of the trials and tribulations of the character Job, the poet of Job reflects upon his world vision and creates new metaphors of the God concept, in fact, a new and different God construct. Hubble (1998:32) has shown that religious models and metaphors, including God constructs, lose their effectivity when life's experiences do not fit these models, or when the God constructs are experienced as dominating, depressing or negative:

In times like these human religious discourse deepens, it becomes critical and transforming by nature, and develops new metaphors or God constructs that are more effective and offer better existential solutions. (Hubble 1998:32)

This is what happens in Job chapters 38-41. The personifications and metaphorisations that Job observes function to establish a convincing and new real image of God: '... now my eyes have seen you'. This paves the way for a new value system. This value system incorporates certain important principles as exposed in God's address to Job (for an extensive list see Venter 2006:240-246, and for a summary Venter \& Viviers 2008:250-268; also for an elaborated list of resources). What follows is a brief mention of some of those principles.

\section{Knowledge and control}

YHWH's address is all about observation. It is important, however, to note the relationship between observation, control and wisdom. An ambivalence exists in the epistemic process, according to which the idea of knowledge or wisdom always functions in two directions: from subject to object, and also from the observed object back to the subject (Malul 2002:193). This has specific reference to the notion of control. Even in wisdom concepts such as the construction of a God figure, this ambivalence should be noted in a context such as the one the Job character finds himself in, being encouraged to observe and learn. When the hitherto unknown subject becomes 'known', it also establishes a manner of control over the observer. This suggests some relinquishing of control over the object, and whereas Job is encouraged to observe in the same way God does, the ideology behind the God character assumes new 
dimensions. In fact, the validity of a God character depends upon the inherent balance, or homeostasis, or interactivity in terms of control and arbitrariness. This is especially valid as far as known dualisms such as gender is concerned, but I suggest it is also valid for other dualisms, such as poverty and wealth, or authenticity and fallacy.

Has Job learned that he himself is not in control of everything that he observes or owns? Has Job learned to relinquish his own opinions about and control over his friends and daughters, amongst others?

\section{Differentiated unity}

A basic characteristic of all matter and therefore all life is the complex, creative, interchanging dynamic between opposing forces (Bechtel 1995:223-237). These forces include life and death, control and randomness, order and chaos, and more. The destruction of one of these forces causes the destruction of the opposing force. Human cognitive processes recognise this principle, for example that life and death form a differentiated whole, and expect from their gods to be able to encompass both, thus making eternal existence a possibility ${ }^{4}$. Of course this entails the necessity, even within a God construct, of a balance between control and randomness.

Randomness is just as vital for existence as control. To eliminate randomness for the sake of control is to make life itself impossible. Just as important is the value of opposing forces. Since opposing forces exist in unity, the one polarity is not inherently bad, as the other is inherently good. Good and bad are human constructions, born from human bodily experiences, and is but part of the evolutionary process of securing the existence of the species. The category 'bad' is created by the human inability to differentiate between, accommodate and appreciate the differentiated unity of opposing forces. Bechtel (1995:228) states: 'Each of the oppositional forces can be used either destructively or creatively. The responsibility is on humanity, not some outside force'.

Unfortunately theology often advocates the destruction of arbitrariness and randomness in its quest for control and power. Patriarchal old Israel and our well-known Western dualisms are two results of this power play; so also the problematic God construct of the narrative part of Job who colludes with Satan against Job.

I wish to suggest that there is a difference in the poetic address in chapters 38-41. Perhaps this God allows arbitrariness; perhaps randomness is part of this cosmology and the controlling mighty Israelite masculine God bites the dust, or perhaps some traces of the recognition of a differentiated unity allow some space for a not so very powerful masculine God. In this regard the observation by Fox (2011) should be noted:

In the book of Job, he overrides justice for another reason: to allow for a human loyalty that is pure, unbought and unstinting.

4.Even the complexity of gender as element in differentiated unity has to be encompassed meaningfully by the ideal God construct.
God is not amoral or anarchic, but he is constrained by the logic of his own demands, and these require allowing the world to be imperfect. Humans must respond with faith in God's goodness in spite of the world's - and God's - imperfection. (p. 159)

Has Job recognised his own imperfections, and learned that differentiation in terms of circumstance, prosperity, social relations and family behaviour is not an indication of chaos, but inherent to life, and God himself?

\section{Homeostasis}

The address of YHWH to Job reflects a metaphorical extension of an idealised, homeostatic body (Viviers 2002:519, 522). Nature and cosmos are no objectivistic stating of the facts about creation, and it is no divine or mystical revelation, even if it is presented in the form of a cosmology. It is simply a declaration of a harmonious, healthy, balanced macro cosmos, as a model for humans to strive to attain. If Job has learned about this vital ingredient of life, the ultimate goal and ideal for human existence, namely balance, his newly found balanced world view and mode of social interaction is explained.

\section{Eco-justice}

Particularly valuable values inherent to YHWH's speeches emerge if the text is read through the lens of eco-justice. Not only has eco-justice been elevated to an important model in theology, it has also become a politically and emotionally charged vital issue.

Life in its fullness can only be lived in just and fair relations with all creatures on earth. Therefore people demand from the powers that be, and that includes all and any God constructs, to provide the necessary space for the continued existence of the diversity of natural habitats and creatures that make up our existence. In a securely contextual analysis of Job 38-41, the principles of eco-justice provided a paradigmatic framework for the rescue of the perceived disruption between the poetic and prose components of the book, specifically as far as the epilogue is concerned. The following principles, amongst others, have emerged from the text.

\section{The principle of intrinsic worth}

The cosmology in Job 38:1-41:25 shows a lack of hierarchising of creaturely entities. Humankind is conspicuously in the background. God's world is an inductive world where the individuality and intrinsic worth of every creature leads to appreciation. This is in sharp contrast to the world of deductive hierarchy and dependence of Job and his friends. In the epilogue Job is depicted as devoid of any or most typically hierarchising characteristics. His daughters are regarded with respect and are acknowledged, contrary to what Clines (2011:1239) observes when he says that the inheritance endowed to the daughters is no 'proto-feminist impulse', nor a retraction from previous patriarchal attitudes: it happens solely because of their beauty. Furthermore, as was shown earlier, the masterslave component of Job's earlier wealth is remarkably absent 
in his second life. It has even been suggested by Scholtz (2013) that Job's wife found a new life alongside this renewed Job, after previously being dismissed as foolish:

Yet, as hinted at in the nature of the first set of children, Job's wife was surely someone with an appetite for life. Together with Job she has more children - a transformative experience for him in which she draws him over to a different way of being in the world, which she has always embodied. The nature of Job's transformation, in which his wife plays such a significant part, is further elucidated in his relationship with his three daughters - a relationship in which the presence and influence of his wife can also be recognised. ${ }^{5}$ (p. 830)

\section{The principle of interrelatedness}

This cosmos is not anthropocentric. In the world vision of the address to Job creation is a structure where humans accept the place assigned to them, in fact only one of the animals on earth (Viviers 2002:516). The creation of man and woman is not mentioned at all, and 'this is no coincidence!' (Maier \& Schroer 1998:191). In earlier cosmologies man achieved the status of ruler, dominator and perhaps conservator of the cosmos based upon a male body ideology. In this cosmology in the book of Job man is depicted as creature within a process of evolutionary growth, as both subject and object, integrally part of the whole of creation. With the depiction of interdependent biodiversity, where meteorological, biotic, geological and even mythological creatures form a harmonious whole, without the care or domination of a human, mutual interrelatedness is acknowledged as the foundation, the building block of life. No wonder that Job is found enveloped in healthy relationships with family and friends in the epilogue. No wonder these relationships contribute to prosperity and a full life: the God of mutual interrelatedness is firmly inscribed in his value system.

\section{The principle of mutual care}

In the biodiversity of creation a dynamic interaction takes place. An example is the caring role fulfilled by creatures simply by existing naturally, for example, the buffalo preparing the grass for the herbivores, and the abundance of ostrich eggs providing food for the Egyptian vulture. Examples of the principle of mutual care that arise from an ecological reading of the book of Job are multiple. Intrinsic to the metaphor of a balanced harmonious body is the diversity of parts that finds the purpose of its existence not in domination, but in care for the whole. Mutual care forms part of the cosmic framework and the dynamics of YHWH's address to Job. ${ }^{6}$ This becomes very clear when it is recognised 5.For an exposition of the transformation of gender values in God's address to Job,
see again Venter (2006); also for more eco-justice principles uncovered by a bodycritical analysis.

6.The ostrich is described as a bird without any wisdom in Job 39:20. Yet observing one in the wilderness and reading the text through an ecological lens dramatically exposes the vital necessity of ostriches' trust in arbitrariness and randomness in nature. Furthermore it is a perfect example of authentic existence which translates into interdependence and mutual care. A male ostrich will gather a harem of females, and as many as 25 eggs are laid in a nest on the bare ground. However, only females, and as many as 25 eggs are laid in a nest on the bare ground. However, only
two or three chicks hatch in a season. This might seem senseless. In fact, even the two or three chicks hatch in a season. This might seem senseless. In fact, even the
author of Job was caught out in his or her ignorance about ostriches; but consider the Egyptian vulture, another endemic African species. Its staple food? The (surplus) the Egyptian vulture, another endemic African species. Its staple food? The (surplus) eggs of ostriches. We may well ask: why such a wasteful surplus of eggs? Of what
use is a wealth of eggs if only three or four are hatched? The Egyptian vulture as a species is grateful for this harmonious co-existence between 'poverty and wealth'. that a substantial degree of typical femininity exists in die depiction of the Creator, analogue to a mother reminding her children to care for each other (Venter 2006:245).

\section{A new God}

For the character Job the wilderness experience created a convincing 'ideal body', a convincing metaphor of godliness, essentially a 'new God'. This is what happens when you observe: you suddenly know that life is not about reward or punishment, it is about reciprocal constitution, intersubjectivity, balance and harmony. Intersubjectivity by way of mutual incorporation of all values is the powerful mechanism the natural world unleashes on human experience; that also is the mechanism of God's address to Job. It is simply a declaration of a harmonious, healthy, balanced macro cosmos, as a model for humans to strive to attain.

\section{A new value system}

The wisdom of the poem lies in the metaphorisation of a differentiated unity, a balanced body. Within this unity life is possible exactly because there is space for all creatures that exist in dynamic interaction and mutuality. Life is possible (as part of the cosmological design) because every creaturely entity contributes thereto. God's role is to create and allow space for life. Therefore the important value of mutual interrelatedness, amongst others, is introduced as a godly way of life.

No element in creation is regarded as unwelcome, threatening life, or inherently evil. Intrinsic to the metaphor of a balanced harmonious body is the diversity of parts that find the purpose of its existence not in domination, but in care for the whole. Mutual care forms part of the cosmic framework and the dynamics of God's address to Job. Within this cosmic framework there is no space for discrimination against women, or daughters, neither is it possible to have an authentic human existence through the exploitation of others by owning them as slaves or servants.

\section{A qualitative alternative}

As illustrated by the epilogue, a qualitative alternative to the ideology of justice and retribution is established by Job's transformation, not only from poverty to wealth, but specifically from being regarded by himself as a victim of an unjust God, to a man with a full life, as a result of his new relationships. Jurgen Moltmann (2012) says:

The qualitative alternative to poverty and wealth is community. In a community determined by solidarity, all its members become rich in relationships, in brothers and sisters, friends and neighbours, comrades and colleagues, rich in trust. In communities like this, in most cases we can help ourselves. Men and women are there for each other, so their ideals, their abilities, and the means at their disposal are available for all of them. (p. 66)

The emphasis on individualisation rather than community makes people in modern societies powerless and open to manipulation. On the other hand, amalgamations at grass 
roots for the purpose of a shared life call up the power of the people, and a community for the common good is created in which everyone can acquire a just share. Only injustice makes poverty a torment. Only the dissolution of community kindles just anger.

Therefore a reversal in convictions and basic values is necessary, as well as a reversal in the attitude to life and the conduct of life. What are the interests and values governing our scientific and technological civilisation? To put it simply: the main concern is the boundless will for domination which has driven men and women to seize power over nature and over each other, and continues to do so. This reversal in basic convictions should begin with our picture of God from which we take our sense of direction. The consequence will be a turn away from one-sided domination, and a turn to mutual community, or ubuntu.

Gutiérrez (1987) summarises the message of the book of Job as follows:

The world of retribution - and not of temporal retribution only is not where God dwells; at most God visits it. The Lord is not prisoner of the 'give to me and I will give to you' mentality. Nothing, no human work however valuable, merits grace, for if it did, grace would cease to be grace. This is the heart of the message of the book of Job. (pp. 88-89)

Brueggemann (2003) has this perspective:

Inspired by the experience of his own innocence, Job bitterly criticized the theology of temporal retribution as maintained in his day and expounded by his friends. And he was right to do so. But his challenge stopped halfway. God subsequently rebuked Job for remaining prisoner of his either-or mentality. What he should have done was to leap the fence set up around him by his sclerotic theology that is so dangerously close to idolatry, run free in the fields of God's love, and breathe an unrestricted air like the animals described in God's argument - animals that humans cannot domesticate. The world outside the fence is the world of gratuitousness; it is there that God dwells and there that God's friends find a joyous welcome. (p. 303)

This is exactly what happened in Job 38-41: God took Job 'over the fence' and introduced him to stars and the sea, and the lion and the ostrich, and many more examples of this gratuitous world contained of reciprocal observation, differentiated unity, homeostasis, an (eco-) just world governed by intrinsic worth, interrelatedness, and mutual care.

I propose that re-imagining a discourse of reconciliation and social cohesion in our world could benefit from the cosmic framework of interrelatedness, grace and mutual care as established by God's address to Job: a lesson from the wilderness, as it were. In this new world of reconciliation and community at least exploitation of others into servitude and slavery and discrimination against women will have no place, and might lead to lives 'satiated with days' for all God's creatures.

\section{Conclusion}

It was stated previously that the book of Job is about Job's transformation. This transformation is not only depicted by new relationships and a surfeit of wealth and prosperity, but occurs within Job's inner person when he comes face-to-face with the wonders of creation. In psychological terms it could be said that Job underwent a change or transformation of ego. Yet all revolves around the Creator and the principles inherent to creation as described by the Voice from the storm. Job was enlightened and died in fullness of life, but perhaps Carl Jung (1960) should remind us about the real source of life in its fullness when, in his Answer to Job, he says:

... even the enlightened person remains what he is, and is never more than his limited ego before the One who dwells within him, whose form has no knowable boundaries, who encompasses him on all sides, fathomless as the abysms of the earth and vast as the sky. (p. 108)

\section{Acknowledgements Competing interests}

The author declares that he has no financial or personal relationships which may have inappropriately influenced him in writing this article.

\section{References}

Bechtel, L.M., 1995, 'A feminist approach to the book of Job', in A. Brenner (ed.), A feminist companion to wisdom literature, pp. 222-264, Sheffield Academic Press, Sheffield.

Brenner, A. 1997, 'Job the Pious?', in D.J.A. Clines (ed.), The poetical books: A Sheffield reader, pp. 298-313, Sheffield Academic Press, Sheffield.

Brueggemann, W., 1994, A social reading of the Old Testament, Fortress, Minneapolis.

Brueggemann, W., 2003, An introduction to the Old Testament; The Canon and Christian imagination, Westminster John Knox, Louisville.

Clines, D.J.A., 2011, Word Biblical commentary volume 18B: Job 38-42, Nelson, Nashville.

Davis, E., 2001, Getting involved with God: Rediscovering the Old Testament, Cowley, Lanham.

Dhorme, E., 1967, A commentary on the book of Job, Nelson, London.

Fox, M.V., 2011, 'Reading the tale of Job', in D.J.A. Clines \& E. Van der Wolde (eds.), A critical engagement: Essays on the Hebrew Bible in Honour of J Cheryl Exum, pp. 146-162, Sheffield Phoenix, Sheffield.

Guillaume, P., 2008, 'Dismantling the deconstruction of Job', Journal of Biblical Literature 127(3), 491-499.

Gutiérrez, G., 1987, On Job: God-talk and the suffering of the innocent, Orbis, Maryknoll.

Hubble, R.A., 1998, Conversations on a dung heap: Reflections on Job, Liturgical Press, Minnesota.

Jung, C.G. 1960, Answer to Job, Princeton University Press, Princeton.

Maier, C. \& Schroer, S., 1998, 'What about Job? Questioning the book of "The righteous sufferer"', in A. Brenner \& C. Fontaine (eds.), Wisdom and Psalms: A feminist companion to the Bible, pp. 175-204, Sheffield Academic Press, Sheffield.

Malul, M., 2002, Knowledge, control and sex. Studies in Biblical thought, culture and worldview, Archaelogical Center, Tel Aviv and Jaffa.

Moltmann, J., 2012, Ethics of hope, Fortress, Minneapolis.

Newsom, C.A., 1996, 'The book of Job: Introduction, commentary and reflections', in E. Leander, F.B. Craddock \& C.C. Black (eds.), Volume 4 of the new interpreter's Bible, p. 361, Abingdon Press, Nashville.

Newsom, C.A., 2003, The book of Job: A contest of moral imaginations, Oxford University Press, Oxford.

Ngwa, K.N. 2005, The hermeneutics of the 'happy' ending in Job 42:7-17, De Gruyter, Berlin.

Scholtz, R. 2013, “'I had heard of you ... But now my eye sees you”: Re-visioning Job's wife', Old Testament Essays 26(3), 819-839.

Van Wolde, E.J., 1994, 'Job 42,1-6: The reversal of Job', in W.A.M. Beuken (ed.), The book of Job, pp. 223-250, Leuven University Press, Leuven. 
Venter, P.P., 2006, Vroulikheid by die Skeppergod? ' $n$ Liggaamskritiese Ontleding van geselekteerde Skeppingstekste in die Ou Testament, PhD thesis, Department Biblical Studies, University of Johannesburg.

Venter, P.P. \& Viviers, H., 2008, 'Creator God as feminine? A body-critical analysis of selected creation texts in the Old Testament', Verbum et Ecclesia 29(1), 250-268.
Viviers, H., 2002, 'Body and nature in Job', Old Testament Essays 14(3), 510-524.

Wicke-Reuter, U., 2000, Göttliche Providenz und mensliche Verantwortung bei Ben Sira und in der frühen Stoa, De Gruyter, Berlin. http://dx.doi. org/10.1515/9783110814415

Wolfers, D., 1995, Deep things out of the darkness. The book of Job and new English translation, Kok, Kampen. 